УДК 82.091(497.11)(437.3)

https://doi.org/10.18485/msc50_vuk_trsic.2021.ch7

Карел Хоралек

\title{
ВУК СТЕФАНОВИЋ КАРАЏИЋ И ЈОЗЕФ ЈУНГМАН
}

(Типолошко поређење)

Ове године чешки народ слави двестогодишњицу рођења Јозефа Јунгмана, чија је делатност у много чему сродна с делатности В. Стефановића Караџића. Јунгман и Караџић су два истакнута представника словенског препорода. Као филозофи, књижевници и културни посленици, они су на одлучан начин одређивали карактер културног покрета својих народа. У њиховој делатности има не мало сличног, не мало подударних црта. Исто тако и не мало својеврсних и специфичних црта. Ова својеврсност условљена је, пре свега, специфичношћу историјско-друштвених односа. У чешком културном покрету епохе словенског препорода Јунгман већ има неколико претходника међу које спада и Јозеф Добровски.

Стога се може рећи да је у српском препороду Вук Ст. Караџић имао да уради онолико колико у чешком препороду цео низ културних радника. Јунгманову делатност отежавали су неподесни услови, али, без обзира на то, он је имао лакши посао јер се налазио у смиренијој средини и имао погодније услове него Вук Караџић.

Караџић се родио 1787. г., он је, наиме, 14 година млађи од Јунгмана. Ова разлика у условима заосталости културног живота у Србији изгледа незнатна. Али утолико пре се овом разликом може објаснити понека специфичност у културној оријентацији Караџића, нпр. његова тешња веза с романтизом, а исто тако, и с реализмом. У односу на то Јунгман је знатно ближи књижевном класицизму јер је ватрени поштовалац Волтера и француског књижевног сентиментализма.

У теоријским радовима Јунгмана класицистичка оријентација се изражава јаче него ли у његовој књижевној делатности. Од Јунгманових књижевних превода највише романтичарских елемената садржи превод Шатобријанове „Атале”. Блискост Караџића романтизму јасно доказује његов однос према народном уметничком стваралштву. Јунгманов однос 
према народном стваралаштву јасно сведочи о томе да се његов уметнички укус фомирао, пре свега, под утицајем песника онога типа с чијим делима је он преко превода упознао чешку интелигенцију свога времена (то су били Милтон, Гете, Шатобријан и др.).

У књижевним и језичким погледима Јунгмана централни значај има схватање да је уметнички квалитет дела условљен израђеношћу и нивоом развоја књижевног језика. Својом научном и преводилачком делатношћу Јунгман је тежио ка усавршавању чешког књижевног језика. У томе је он видео неопходан услов без кога је незамислив даљи развитак литературе уопште, а делимично и уметничке.

Вук Стефановић Караџић је стандардизацију народног језика, његову елементарну припремљеност за опште културне функције сматрао за свој главни задатак. Он је и прости народни језик сматрао као добро и подесно оруђе не само за изражавање научне мисли него и за поетско стваралаштво. И њему се чинило да су за то неопходни услови прилагођавања народног језика општекултурним фунцијама.

Карактеристици Јунгмана треба додати да му класицистичка естетика и гледишта о улози језика и поезије нису били сметња да према неким појавама романтичарске поезије заузме позитиван став. И својом теоријом Јунгман је на прелазу ка романтизму. Најближи му је био романтизам класицистичког типа који у словенским књижевностима има сјајне представника у Пушкину, Мицкјевичу и Словацком. У чешкој поезији овом литерарном типу најближи је Челаковски, а, можда, још и Ербен. Према поезији с фолклорним елементима, ка којој је пут отворила и Караџићева сакупљачка делатност, а која је у Чешкој у В. Ханки имала свог првог поклоника, Јунгман се није поставио ни с одушевљењем ни негативно. У веродостојност Ханкиних плагијата Јунгман је веровао и у њима је видео дивне плодове људског стваралаштва. Међутим, у „класичну" литературу их није могао уврстити већ из простог разлога што су били слободна апликација прозодијског система Добровског (а на свој начин и правила чешке народне поезије, чега ни Ханка у време кулминације својих стваралачких снага није био посве свестан).

Додирне црте, а истовремено и разлике, између Јунгманове и Караџићеве књижевне деланости добро се дају сагледати на њиховим преводима. Јунгман је својим преводима хтео, пре свега, да послужи неговању и обогаћењу поетског језика. Избором текстова за превођење (Милтон, Шатобријан, Гете и др.), Јунгман се усмерио, углавном, на тада још малобројну чешку интелигенцију. Није још тежио ка придобијању ширих читалачких крутова; ови су се још до доласка Тилове генерације 
морали задовољити књигама народне литературе (nem. Volksbücher), које је настојао да модернизује В. М. Крамеријус.

Караџић је, при настојању да наметне „народни” тип књижевног језика, морао да се супротстави не само језичком него и књижевном конзервативизму чији су носиоци били, већином, представници православне цркве. Својим преводом Новог завета дефинитивно је учврстио своју реформу и права је штета што се тога посла латио релативно касно; објашњава се то тиме што је превођење захтевало већу филолошку припрему него рад на граматици и речнику. У употребу новог превода библијских текстова није требало сумњати, црквени кругови нису могли, у вези с тим, заступати мишљење да потребе задовољавају и прерађени црквенословенски (славеносрпски) текстови кад је и у Русији одобрен нови превод на народни језик.

На крају желео бих још да кажем да при поређењу теоријских погледа Јунгмана и Караџића наилазимо на тешкоће када је реч о теорији Вука Караџића. Он готово уопште нема теоријских радова који би се односили на научнокњижевна питања. У Јунгмана је то сасвим друкчије. Његова „Словесност” - практично-теоријски увод у теорију књижевности - а заједно с тим и хрестоматија поетских текстова, садрже комплетну Јунгманову теорију. Што се Караџића тиче, основе његове теорије књижевног стваралаштва треба тражити у предговорима његовим сабраним народним песмама, у његовој кореспонденцији и у другим изворима. Морам признати да ја Јунгманову теорију поредим, до извесне мере, са реконструкцијом теорије В. Караџића.

Превео: Д. М.

* Рад је претходно објављен у зборнику Научни састанак слависта у Вукове дане, 3, 261-263. 